
IUB. Unfortunately the possibility of Soviet scientists being banned as officials was not considered by the organizers at any time during the interim period. A spokesman from foreign affairs believes the problem could have been overcome by consultations beforehand.

The stage was thus set for the imbroglio at the conference, the first IUB congress in Australia. The Soviet participants waited until the last minute to apply for visas, and just a few days before the conference the ban was announced. Appeals from the president of the Australian academy (Professor Arthur Birch), the premier of Western Australia (Mr O'Connor) and the Swedish Academy were all to no avail. It was too late for the government to back off gracefully.

Reactions at the congress were mixed. Professor Frank Gibson of the Department of Biochemistry, John Curtin School of Medical Research, Australian National University, says "disappointment at not hearing Professor Ovchinnikov's lecture was the main reaction". Lack of travel funds, and the relatively high cost of internal air fares and accommodation limited the number of overseas registrants, particularly from the United States.

The academy now faces the unenviable task of persuading the government to change its policy in the week before the ICSU meeting. Failing this, it will try to delay any precipitate action at the meeting. Nevertheless international censure may be just the prod the government needs to review its policy on sanctions. Significantly, the International Union of Pure and Applied Chemistry succeeded in securing the admission of Israeli scientists into India for a conference on the applications of the Mossbauer effect held in Jaipur last December. Vimala Sarma
These reservations were not passed on to

\section{European space technology Ariane set to go}

The delay to the fifth launch of Ariane, rescheduled from last April to tomorrow, has had its effects on the vehicle's future launch programme. But careful reorganization of the launch schedule up until the end of 1984 seems to have ensured minimal damage to the launcher's commercial prospects.

The five month delay has been caused by problems with Marecs B, one of two satellites that the fifth Ariane will put into geostationary orbit. Marecs $\mathbf{B}$ had to be modified after problems with electrostatic charging on Marecs $\mathbf{A}$, the sister satellite launched by the fourth Ariane late last year. The first effect of the delay has been to reduce the number of Ariane launchers this year from four to two. The next launch now scheduled for November will put Exosat, the X-ray observatory built by the European Space Agency, into polar elliptic orbit, more or less on its target date. But the launch of ECS 1, a communications satellite, is being delayed to early next year and Intelsat, the international telecommunications satellite organization, which was to have launched the sixth Intelsat $\mathrm{V}$ satellite aboard Ariane in October or December this year, has taken that part of its custom elsewhere.

Intelsat, however, has not reduced its overall commitment to Ariane. The launcher will now put Intelsat V numbers 7 , 8 and 9 into orbit next year instead of numbers 6,7 and 8. Next year's launch programme has been rescheduled to include six launches, the maximum possible with the present launch pad, instead of five originally planned.

Ariane is now fully booked with firm orders until the end of 1984, according to

\section{Now even MIT has troubles \\ Washington \\ connections at that time.}

Even well-off US universities are not immune from the financial squeeze affecting US higher education. The Massachusetts Institute of Technology (MIT), which has an operating budget of $\$ 500$ million, reports that it had a deficit of $\$ 2$ million for the year just ended. Next year's deficit could be $\$ 4$ million. Consequently, it has now announced plans to cut costs and, among other things, to lay off 400 employees.

Unlike both the California Institute of Technology and Stanford University, with which MIT is often compared, MIT has a relatively small endowment and thus a harder cushion for hard times. The current deficit is not MIT's first; it had a deficit in the early 1970s, when it lost the extra income and overhead funds that went with the Charles Stark Draper Laboratory, from which it severed its
According to provost Francis E. Low, approximately two-thirds of MIT's operating budget is composed of funds that come in each year to operate facilities such as the Lincoln Laboratory, with little control or financial benefit to the rest of the institute. To control rising costs, then, the institute must look to the $\$ 120$ or $\$ 130$ million in general funds that pay for education and its administration. To prevent rising deficits, these activities will have to be reduced. There will be some faculty reduction through normal attrition, causing a loss of approximately 30 positions. Also, 200 other people will be allowed to leave through attrition in the next few years, he says, while an additional 200 will be laid off. Low thinks the institute can afford some belt-tightening: "It [MIT] functions in some respects in a luxurious way". Deborah Shapley
Arianespace, the company that will take over commercial operation of the launcher some time next year. Just two places remain to be firmly negotiated for 1985 and a number of reservations, for which customers must pay $\$ 100,000$, are apparently in hand for future years. But Ariane has now lost some early reservations from customers who have eventually plumped for US facilities and Arianespace acknowledges that the fifth launch of the shuttle in November, which will put a satellite into geostationary transfer orbit, could take the edge off Ariane's seeming attractiveness.

The next few Ariane flights will still be formally in the hands of the European Space Agency. Arianespace will take over operations and start earning revenue from launches from the middle of next year, probably after the tenth flight. The company hopes that by 1985 the capacity of the launch facilities at Kourou in French Guiana will increase from 6 to 12 when the second launch pad, now under construction, comes into operation. Arianespace expects to start showing a modest but respectable profit in 1985. But future prospects will also depend on the success of the space shuttle. The latest estimate is that customers will have little to choose between the two on price. Reliability, service and convenience could be most significant.

Judy Redfearn

\section{Australian science politics}

\section{Labor's policy}

\section{Canberra}

The Australian Labor Party, more hopeful than ever that it will form the next federal government but less certain now than a few weeks ago that the general election will come soon, formally adopted a new policy on science and technology at its biennial conference here in July. Although the policy is vague enough not to be a constraint on Labor members of parliament, the convention that conference decisions are binding on elected representatives may yet cause trouble.

The new science policy was adopted on the nod on the last day of the conference, when most delegates were packing up to go home. On the face of things, science and technology have only low priority, at least compared with the uranium issue. The conference heard a sustained and embittered debate on the question of whether Australia under Labor would honour existing uranium contracts. That issue remains unresolved, although the conference confirmed the principle that Labor will supply uranium abroad only on tough conditions.

The cornerstone of the Labor Party's policy on science and technology is economic - government spending will bring prosperity and economic growth. $\mathrm{Mr}$ William Hayden, the leader of the party, and his colleague with responsibility for 
science and technology, Mr Barry Jones, have repeatedly said as much.

Perhaps significantly, the present Liberal-Country Party coalition government has responded by increasing support for the Industrial Research and Development Incentives scheme from A $\$ 14$ million to $\mathbf{A} \$ 50$ million. More broadly, the government has taken to justifying a more interventionist approach to Australian industry by references to "market imperfections".

\section{More animal care Washington}

Public pressure for a change in rules governing the care of laboratory animals has prompted the National Institutes of Health (NIH) to tighten up their requirements, whether or not Congress acts on the matter this year.

NIH will require that at least one nonscientist be appointed to each research institution's animal care committee the groups charged with overseeing the treatment of experimental animals. This echoes one of the requirements in the bill now before Congress. (The bill, renumbered HR 6928, has cleared the House Science and Technology Committee and is now before the health and environment subcommittee of the Energy and Commerce Committee.)

NIH is also planning to mount a series of site visits to check on the extent to which researchers are complying with NIH guidelines. Under current rules, recipients of NIH grants must agree to adhere to the practices outlined in NIH's Guide for the Care and Use of Laboratory Animals. Failure to do so can result in loss of NIH funding. A major criticism of the system, however, is that too much reliance is placed on the good-faith assurances of the researchers and too little on inspection.

But NIH is not yet ready to order on its own another change in the proposed legislation: the mandatory accreditation of all research institutions by an independent group such as the American Association for Accreditation of Laboratory Animals Care (AAALAC), which sets standards and conducts routine inspections every three years. According to Dr William Raub, NIH's associate director for extramural research, "We think the concept of accreditation makes a lot of sense. But we're not yet, at least, willing to mandate it until we know more about the costs". Universities have claimed that bringing all NIH-supported institutions up to the AAALAC standards would cost $\$ 500$ million. The legislation before Congress would eventually require all institutions to meet the AAALAC standards, but would soften the blow by allowing ten years in which to meet this goal.

Stephen Budiansky

Labor is less inhibited about intervention. The July conference undertook that research and development expenditure should increase from the present 0.9 per cent of gross national product to a level "equivalent to that in other technologically advanced countries". Prudently, Labor did not specify a target figure.

What Labor of fers is more pragmatic a promise of a new division in the Department of Science and Technology to be concerned with industrial research, development and innovation. A Labor government would be a dutiful customer for new Australian products, and would back technical innovations with hard cash. It would also provide venture capital for new kinds of industrial developments, in biotechnology for example.

On issues such as these, the parties differ only moderately. Neither will increase

\section{Mexican science in money trouble}

\section{Mexico City}

In the face of Mexico's present economic crisis, the country's expensive and ambitious programme for science and technology now faces shocking sudden austerity. "A crisis can be good," says Pablo Rudomin, the distinguished neurophysiologist who is president of the Mexican Academy of Sciences. "It leads you to deep thoughts about where you're going. I think it [the crisis] will give us a sense of community. We'll have to work on priorities, and quality and on preserving what we have."

What has happened is that after a decade when the economy was flooded not just with domestic oil revenues but with loans from foreign banks (chiefly in the United States), Mexico has found that it cannot pay the instalments due on its debts, estimated at $\$ 80,000$ million. The payments were rescheduled in August, since when the Mexican banks have been nationalized. All sectors of the economy will have to be cut back, but just how will not be known until the new government of President Miguel de la Madrid Hurtado takes office on 1 December.

"Things will change, but probably for the good," echoes economist Manuel Gollás, who holds a key political post as head of the advisers to the director general of the Consuejo Nacional de Ciencia y Technologia (CONACYT), the Mexican science agency. One irony of the boom, he reflects, is that sometimes "we had more money than we did worthwhile projects".

Supported with government oil revenues and announced with a great fanfare at the beginning of President José Lopez Portillo's 6-year term, Mexico's science and to technology programme was designed to strengthen the infrastructure of science and to encourage Mexican selfsufficiency in technical matters. The programme was nothing if not ambitious. Basic research did well, but there were also spending on basic research. The best hope is that Labor would not let research funds be eroded by inflation.

Long-standing disagreements persist, however, about the role of foreign corporations in high-technology industries. Labor would require foreign corporations to carry out some research and development in Australia, but $\mathrm{Mr}$ Barrie Jones seems well aware that he must find a form of words not so restrictive that foreign corporations will be driven away.

The new Labor policy also promises innovations to give high relief to Australian science. The conference approved a plan for an "Australia Prize" of A $\$ 100,000$ for humanitarian scientific achievement, to be administered by the Australian Academy of Science, and an international conference on Antarctic research to reinforce Australia's claim to the largest slice of the Antarctic.

Vimala Sarma

special priority programmes in fields such as agriculture and nutrition. The energy programme included work on nuclear and solar energy production. There were schemes for supporting industrial research, and the government had emphasized the importance of training graduate students.

Interviewed in their respective offices in Mexico City, both Rudomin and Gollás acknowledged that the programme had been criticized as being only a shopping list of unrelated projects, reflecting the interests of individuals and government agencies. Indeed, its execution reflected this pattern. CONACYT, which designed

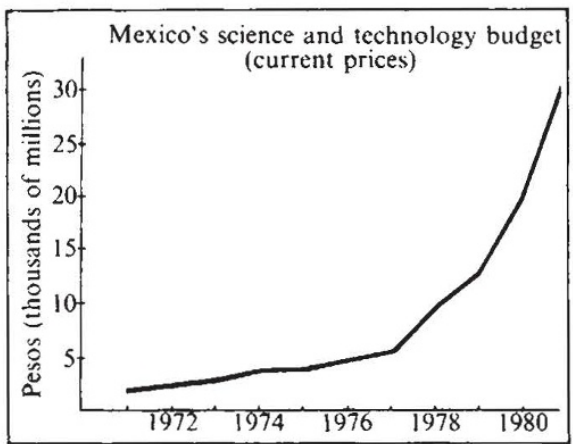

the original programme and serves as the president's science adviser, actually controlled only 11-12 per cent of the total science and technology budget. The government gave the rest directly to universities (the major one being the Universidad Nacional Autónoma de México, whose main campus is in Mexico City). Money for the Institut Politécnico Nacional, for example, comes from the Ministry of Education. Private industry and foundations play almost no part in sponsoring Mexican science.

More than half of CONACYT's budget for 1981 , estimated at 3,899 million pesos, went for scholarships, another $20-30$ per cent for administration, public relations, and publications. Grants for basic science directly to investigators in fact accounted 